\title{
How to establish a good government? Lessons from Lee Kuan Yew in Singapore and Deng Xiaoping in China
}

\author{
Franky K.H. Choi \\ Department of History, The Chinese University of Hong Kong
}

Received 22 January 2018 Revised 24 July 2018 Accepted 31 July 2018

\begin{abstract}
Purpose - Outside the US and Europe, to establish a good government requires more than Western-style democracy. Adopting universal suffrage fully from the Western model is no longer a panacea to reach the ultimate goal of good governance in the East, i.e., to keep promoting socio-economic renovation can be noted as a prerequisite to have further meaningful political advancement in an Asian polity. The purpose of this paper is to explain how to establish a good but authoritarian government in the East.

Design/methodology/approach - Given the good of comparative historical analysis, Lee Kuan Yew in Singapore and Deng Xiaoping in China are selected as both cases for "method of agreement." Further including "argument based on the contrary" to form a context for macro-historical analysis, this paper outlines two characteristics of the duo's authoritarian leadership, namely, Ideologies and Policy-making; and Political Modernization, and hence provides a more balanced reevaluation of their governance.

Findings - Apart from noting how these two Asian giants more or less contributed to their good but authoritarian governments for long in the twentieth century, such a word of authoritarianism to the duo was quite positive to help legitimize their governance, which was far different from many negative views of the Western world.

Originality/value - As theories put forward by Western academics could not entirely justify modernization among Asian societies in the twentieth century, this paper attempts to answer one question: Does the meaning of authoritarianism remain unchanged in the discourse of the East and the West?
\end{abstract}

Keywords Authoritarianism, China, Governance, Singapore, Political leadership, Ideology, Lee Kuan Yew, Deng Xiaoping, Policy-making, Political modernization

Paper type Research paper

\section{Introduction}

From the twentieth century, Asians have increasingly noted that a good government should be better established based on Western-style democracy. To establish a good government in the East, however, requires more than implementing a full version of Western-style democracy. In particular, overemphasizing the usefulness of universal suffrage to help establish a good government in Asia hence should be avoided. Francis Fukuyama (1989), instead of still sticking with his former stance made in The end of history? (p. 1), recently adjusted his view and therefore kept explaining that "the existing measures of state quality or capacity have a number of limitations [...] As the concept of good governance is not well-established, different experts may intend different things when responding to the same

(C) Franky K.H. Choi. Published in Public Administration and Policy. Published by Emerald Publishing Limited. This article is published under the Creative Commons Attribution (CC BY 4.0) licence. Anyone may reproduce, distribute, translate and create derivative works of this article (for both commercial and non-commercial purposes), subject to full attribution to the original publication and authors. The full terms of this licence may be seen at http://creativecommons.org/licences/by/4.0/legalcode

This research paper is partially extracted from the author's $\mathrm{PhD}$ thesis at The Chinese University of Hong Kong. The author would also like to express sincere gratitude to his supervisor, Professor Leung Yuen Sang, Professor of History; and Director of Institute of Chinese Studies at The Chinese University of Hong Kong.
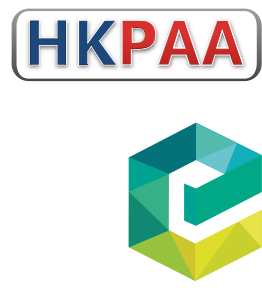

Public Administration and Policy Vol. 21 No. 2, 2018 pp. $107-119$ Emerald Publishing Limited $1727-2645$ DOI 10.1108/PAP-10-2018-007 
survey questions" (Fukuyama, 2013, p. 349). As political figures embodying the merits of authoritarian leadership, Lee Kuan Yew, the founder of an independent Singapore and Deng Xiaoping, the General Architect of Economic Reform and Open-door Policy in postMao China were never recognized as democratic statesmen by Western liberal standards. There is no denying these two political strongmen to be illustrated in this paper were more or less capable, during their tenures to establish good governments considering: policyoutcome benefits; administrative efficiency; and socio-economic advancement as the top priority, instead of heavily stressing an absolute advantage of having check-and-balance inside a government as in the Western world.

Almost no one would question the duo to be prestigious but controversial Asian leaders after the Second World War. As time flies, is not it still necessary to adversely regard authoritarianism following such an Eurocentric definition to be coined in the last century? For instance, Andrew Nathan (1990), a leading scholar in the West, made a negative comment that China under an authoritarian leadership seemed trapped by their own historical root in the 1980s (p. 126). Being the latest and counter response to this, Kishore Mahbubani (2010) praised "the importance of good, strong governance has come back with a vengeance" (p. 208) in the twenty-first century's Asia. In this, I similarly believe, history would reserve room to let human beings positively ponder authoritarian leadership. Notwithstanding the fact there were some flaws and negative impacts of authoritarian governance, the duo as illustrated in this paper were without questioning considered as exceptional cases of good governance engendered by semi- or non-Western-style democracy. For example, Jon Quah aptly summarized Lee Kuan Yew's "commitment to the four principles of meritocracy, incorruptibility, rewarding the talented and rule of law is grounded in his belief in the importance of good leadership." He kept explaining once "applying Richard Samuel's concept of political leadership, Lee Kuan Yew and his colleagues succeeded in stretching the constraints facing them and transformed Singapore from a Third World Country to First World status by 2000" (Quah, 2015, pp. 386-387). Such an affirmative comment on authoritarian leadership proved that the goal of good governance could still be achieved in Asian nations despite their thoughts and practices of semi- or even non-Western-style democracy; and here is my first reason to write for this topic, i.e., to make a kind of more balanced reevaluation of having authoritarian governance in a polity.

Since the duo have become historical figures from one to another, it is timely to reascertain their achievements, i.e., the room of establishing a good government under authoritarian leadership in the East, but not just focusing on their controversies and errors as overemphasized in the past. This is the second reason to keep motivating me in conducting comparative historical analysis in order to illustrate how and why these two political strongmen and their corresponding historical contexts, as well as their consequent decisions that manifested such a political wisdom of their authoritarian governance, were "politically-incorrect" as usually judged in the Western world. Only after deeper discussion and analysis is conducted by different angles, such as in this paper, the wherefores of both becoming successful authoritarian Asian giants can be better comprehended. Whenever possible, the author hopes to explore possibilities of further engaging socio-economic renovation under a more political enlightening mode of authoritarian governance, i.e., to establish a good government in the East without initiating an overall Westernization, which was long ignored by quite a great number of Western scholars in the twentieth century.

\section{Outlines and contents}

Each historical scene is extraordinary and so was every nation. Nonetheless, each political leader shared resemblances with others and so did every political system. In light of this, one, to conduct a comparison in this paper, must accept a supposition: Lee Kuan Yew and 
Deng Xiaoping had their distinctive features; yet, there were still similarities between them. Certainly, not all aspects between them can be compared. Given the good of conducting comparative historical analysis (Skocpol, 1979, pp. 33-40) as the research methodology, i.e., to include "method of agreement" for direct comparison of both cases (Lee Kuan Yew in Singapore and Deng Xiaoping in China) in addition to argumentum a contrario ("argument based on the contrary") for macro-historical analysis, the author picks art of authoritarian governance as the central issue and its related two key issues for comparison: Ideologies and Policy-making; and Political Modernization, for the purpose of helping secure power of both authoritarian leaders (Figure 1).

To help better ponder both the historical background and the casual relationship among the above-mentioned central issue and also two key issues to the formation of such a successful authoritarian governance, the rundown of this paper is to combine long-term, together with short-term, historical factors that simultaneously affected the duo's political behavior, in the purpose of formulating their "die-hard" beliefs on the good of authoritarianism to be an unshakable art of governance while setting up their good governments as time goes by (Figure 2). In terms of long-term historical factors, they could be related to how the research subjects (Lee Kuan Yew and Deng Xiaoping) in specific timeframe (after the Second World War) and specific space (Asia). Long-term historical factors include political, economic and social institutions, which have lasted for hundreds or even thousands of years. Needless to say, long-term historical factors would inevitably affect individuals' situation, i.e., short term historical factors, and stimulate the unique situational-condition in Singapore and China, which differed from Democracies in the West. By the end of this paper, the author hopes to explore if there is room to practically establish a good but authoritarian government in the East.

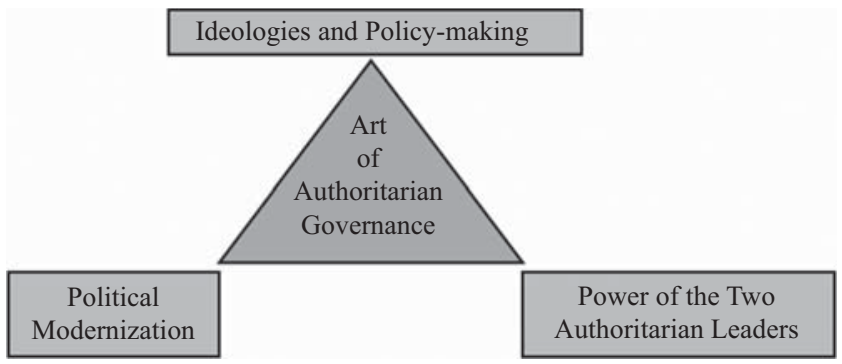

Figure 1. Interlocking relationship of the three main components as Lee Kuan Yew's and Deng Xiaoping's authoritarian governance

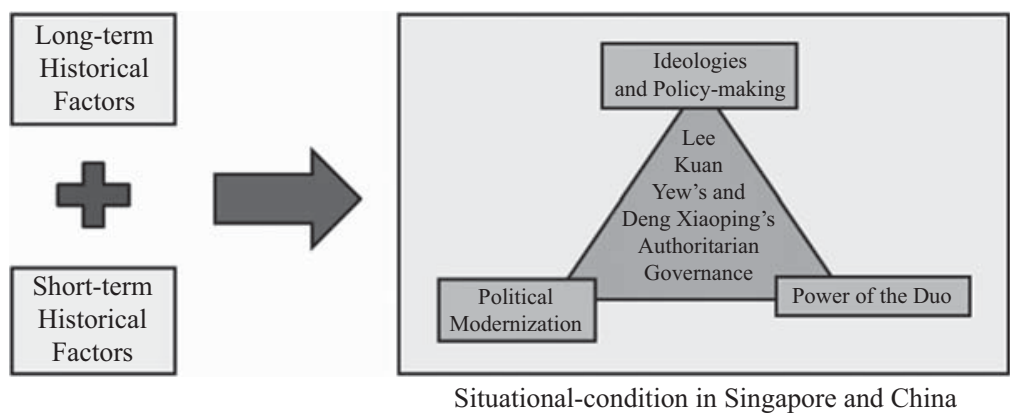

Establishment of the Due's Good Governments not fully Based on an Overall Westernization
Figure 2.

Establishment of Lee Kuan Yew's and Deng Xiaoping's good but authoritarian governments in the context of comparative historical analysis 


\section{Ideologies and Policy-making}

\section{Their adaptations of ideologies in policy-making}

Eurocentrists heavily emphasized Singapore's Lee Kuan Yew and China's Deng Xiaoping regarding the big contrast between their authoritarian governance and that in Western Democracies. However, history proved that this statement was not fully true. Being influential political figures, to maintain power as usual was their ultimate goals when they were top leaders in authoritarian states, but ideologies and policy-making at the same time played a critical role in one-party hegemony or even one-party rule. In particular after the Second World War, the role of ideologies among quite a number of Asian authoritarian states endowed their political leaders with the execution of their ideal political behaviors and hence allowed political elites to implement confidently (Mullins, 1972, p. 509). That is to point out that ideologies initially endow statesmen with the legitimate function; as a result, their policy-making can be supported by ideologies in order to allow both to confidently implement and, once being required, clear political obstacles. Generally, power, ideologies and policy-making to form their authoritarian governance should be always in an interactive relationship.

With an ideological support, both statesmen were capable to introduce policies to strengthen their power, including their legitimacy. However, it is critical to note their ideologies adopted were highly flexible as time goes by, i.e., a series of changes were signifying a departure from the past, while others were just minor changes such as in wordings without alternation of substance. To Lee Kuan Yew, this political leader kept adjusting definitions and interpretations towards the ideologies of the People's Action Party. This was true he had aimed at democratic socialism as his ultimate goal before coming into power. Yet, that kind of a pledge gradually became a blank cheque after being the Prime Minister of Singapore with significant public support since 1959. As a pragmatist, he, under one-party hegemony, had implemented a series of policies against democratic politics, and Singapore was criticized and finally being kicked out by the Socialist International in 1976 (Chen, 1982, pp. 160-161). As for Chua Beng Huat's classification, ideological transformation of this Asian giant could be divided into: ideological leadership in decolonization; elaboration of a "national interest"; on survival and pragmatism; Confucianism; and Communitarianism/Shared Values (Asian Values). This was praised that his successful authoritarian leadership continuously laid on "acceptability to or at least toleration by the population through the presence of an ideological hegemony or consensus" (Chua, 1995, pp. 10-37). In light of this, this paternalistic leader openly permitted, "we did not believe in theories as such. A theory is an attractive proposition intellectually. What we faced was a real problem of human beings looking for work, to be paid, to buy their food, their clothes, their homes and to bring their children up [...] If a thing works, let's work it, and that eventually evolved into the kind of economy that we have today" (Kwang et al., 1998, p. 109). Clearly, his vision on Singapore's economic development should not be bounded by dogmatic ideologies either under the Cold War's mentality or the negative attachment with Foreign Direct Investment, such as many theories about the exploitation of natural and human resources originated from the West. In other words, this political strongman created an idea known as "politics of survival" (Chan, 1971, p. 11), in which both the economic and the political survival were indispensable, while other second-tier considerations such as ideologies came after.

Not surprisingly, such a similar political wisdom was still capable to be exercised well by Deng Xiaoping. Differing from Mao Zedong, socialism as an ideology to this post-Mao leader needed to be better reinterpreted to help consolidate his perceptional reform's basis since the Third Plenum of the $11^{\text {th }}$ Central Committee. As this "big parent" explained, "when everything has to be done by the book, when thinking turns rigid and blind faith is the fashion, it is impossible for a party or a nation to make progress. 
Its life will cease and that party or nation will perish [...] In this sense, the debate about the criterion for testing truth is really a debate about ideological line, about politics, about the future and the destiny of our Party and country" (Deng, 1994, p. 143). In particular, from the viewpoint that Open-door Policy initially took in the remote areas, it could be noted Deng Xiaoping was wary of opening up to the outside world. From 1979 to 1984, cadres in Guangdong and Fujian always struggled to strike the ambivalent balance between what was needed to attract Foreign Direct Investment and what was required to avoid being accused of selling out to those imperialists of the West (Vogel, 2011, p. 411). Fairly, "there is no Deng Xiaoping's vision (ideology) of the economy or the economic system. Thus, while he has intervened repeatedly and forcefully to keep the Economic Reform process moving forward, these interventions have always been precisely calculated for political effect, and extremely vague on economic content" (Naughton, 1993, p. 491). Apparently, the de facto importance of class struggle as specifically reflected in his policy-making sharply declined. In a speech of 1979, this General Architect still insisted class struggle would exist for a long time to come. Yet, it was just noted as "a special form of class struggle" (Chen, 1988a, p. 111). No need to mention that such "a special form of class struggle" was difficult to define and hence to be put into practice, for the purpose of "liberating productive force" in the banner of Economic Reform and Open-door Policy. To be further in line with his policies made during the early 1980s, the term "the acuteness of class struggle" never appeared in 1982's State constitution, but that kind of old-fashioned ideology remained static in the Party constitution of the $12^{\text {th }}$ Party Congress (Chen, 1988a, p. 114), in order to help minimize an intra-party divergence in the debates or even conflicts while stepping forward in Economic Reform and Open-door Policy. That is to say, followed by his "leading from behind the scenes" (Goodman, 1994, p. 91), ideologies include but not limited to Seeking Truth from Facts (1978) and Four Cardinal Principles (1979) were considered as means instead of ends to help him speed up the implementation of his policy-making in full swing and, without doubt, once again strengthen his power (personal authority) and legitimacy of the Chinese Communist Party in governance.

\section{Lessons from their pragmatism to the contribution of domestic politics and international relations}

Instead of governing their regimes as an iron plate, both authoritarian leaders had their strong adaptations of ideologies in policy-making based on temporal situations. Not as similar as many Democracies in the West, there were two important rationales behind their ideological construction at distinctive timings: collective (state) good outweighing individual interests; and disbelief of Eurocentric universal values. In this, the duo strongly believed their policy-making better with regard to the "special national conditions": national interests as utmost concern; strong leadership of having a perennial ruling party; and economic development prior to the political democratization (Choi, 2017, p. 116). In their tenures, they did not fully work based on Western conventions; rather, they adopted flexible ideologies rewarding their nations in the policy-making as time goes by. History told us their authoritarian governance and most related outcome(s) were phenomenal. With their paramount leadership, good governments of Singapore and China were hence established, in particular, both could mostly work under economic miracle in the twentieth century.

Although the duo never regard ideologies as the fundamental guiding principle in policy-making, they tended to reposition ideologies as positive justifications in the later process of their policy-making. To two leaders, this consideration was especially significant to draw our attention, i.e., their usage of the dual roles of ideologies to the contribution of domestic politics and international relations. On the one hand, they did not fully give up the usage of ideologies under their authoritarian governance, simply because ideologies could be treated as the substitution of Eurocentric universal values (e.g., Asian Values as 
Lee Kuan Yew's diplomatic tool to increase Singapore's value by projecting its soft power, i.e., building up his good reputation on the behalf of Singapore in Asia-Pacific region and on global scale) (Leifer, 2000, pp. 8, 25-27), and as the solution to help end up intra-party debates during the policy-making (e.g., Seeking Truth from Facts and Four Cardinal Principles giving socialist Deng Xiaoping's room by further acquiring capital and technology from the capitalist global economy to his Four Modernizations; Pearson, 1999, p. 174). On the other hand, to reposition ideologies as positive justifications in the later process of their policy-making, both kept revising ideologies in line with policy-making based on distinctive pragmatic concerns as time flies. In this, instead of being bounded by the former dogmatic ideologies to hinder national development of their homelands, putting ideologies as the second-tier status after the policy-making could more or less help them unify reinterpreted ideologies, for the purpose of giving them higher flexibilities in policy-making, in particular to adapt the rapid-changing Cold War's context. Apparently, even without initiating an overall Westernization, both authoritarian leaders still had sufficient time in addition to ample resources in establishing their good governments in an incremental way.

\section{Political Modernization}

\section{Quest for legitimacy in Asian democracy}

Legitimacy is understood as a prerequisite for power and a moral foundation of authority (Guo, 2010, p. 6). Although most agree that democracy is good for the legitimation of a political leader, the understanding of this critical concept can be diverse regarding the connotation and its practice. Westerners believe their understanding of democracy is the only truth, and also a representation of cultural hegemony (Wang, 2016, p. 230). Yet, to both authoritarian leaders, their keys in working out political modernization would not be merely picking up representatives through the regularly-held universal suffrage, but working out based on the representation of the people's essential needs. Just as the meaning noted by Hanna Pitkin (1967), people hoped to be governed by their representatives because the meaning of representation was able to comply with their best interests, but "representation need not mean representative government (the one under both the thought and practice of Western-style democracy)" (pp. 2-3). In other words, Western-style democracy was not a panacea to their governance. To Lee Kuan Yew, he claimed that an absolute Western-style democracy without adjustment according to the "special national condition" did not work in Singapore's multi-cultural context. He therefore cited Samuel Huntington's words, "some cultures do not receive democracy well [...] We have built up a democratic system which suits us. In a liberal (Western-style) democracy, a man, once elected, is free from all party discipline. You have that in Singapore, you have unstable government. So we did not say you cannot change sides. You can. But to join the other side you vacate the seat, and face a by-election. That prevents these musical chairs" (Kwang et al., 2011, pp. 53-54). Such a strong disagreement about Western-style democracy would, in the meantime, be Deng Xiaoping's concern. He openly praised, "the greatest advantage of the socialist system (over Western-style democracy) is that when the central leadership makes a decision it is promptly implemented without interference from any other quarters [...] We don't have to go through a lot of repetitive discussions and consultations with one branch of the government holding up another and decisions being made. From this point of view, our system is very efficient." To be obvious, his authoritarian governance was mostly with reference to social order and administrative efficiency (Goodman, 1994, p. 101), but not considering from the needs of holding competitive elections. The aforementioned speeches indicated the duo actualized their authoritarian governance with regard to the political development of their states, and both high-handed political leaders largely hindered the rise of civil society in order to maintain political stability on the national level. Thus, concerning the duo's relevant thought and practice in electoral reform or Political System Reform, their 
coordinated political modernization would still be fine to different extents, even not followed by an absolute road of Westernization.

Regarding the effort paid by Lee Kuan Yew in political modernization, one of his attempts without fully following Western-style democracy was continuously reflected in Singapore's electoral reforms from the early 1980s, including, but not limited to the introduction of Group Representation Constituencies since 1988. To be influenced by the parliamentary electoral setback in 1984, the then People's Action Party failed to capture all parliamentary seats, something that had been long done by Single Member Constituencies from 1968 to 1980, which alarmed Lee Kuan Yew. Besides, there was a 12.6 percent sharp drop in its share of electoral support. Facing such an adverse scenario, this paternalistic leader openly expressed his fear that might enable oppositions made up by a series of low-caliber and non-credible candidates to capture the majority of parliamentary seats. What is more, he deeply noted Singapore's success that was based not only in accordance with six guiding principles of establishing a good government, but also on "tolerance and understanding among the different races (ethnic groups), which provides the vital foundation for the implementation of these principles" (Quah, 1988, p. 128). Multi-ethnicalism was hence embodied in political modernization, such as in the introduction of Group Representation Constituencies.

Of four suggested measures, this political strongman preferred Group Representation Constituencies to others, for example, proportional representation, although the latter was repeatedly mentioned in public consultations. He kept explaining, "first, it would result in the emergence of ethnic, linguistic and religious political parties. The election activities during the election period may call for the emotional extremism and chauvinism. Second, in accordance with the experiences of proportional representation adopted in Western Democracies, proportional representation almost resulted in a weak government, and made the popularity of coalition governments a common practice” (ed. Xinjiapo Lianhe Zaobao, 1994, p. 195). That is, to this authoritarian leader, having Group Representation Constituencies but without abandoning Single Member Constituencies from 1988 was in fact regarded as a modified electoral system that could help prevent most, if not all, potential difficulties brought by political modernization. Chan (1986) in this regard praised, "in a polity (Singapore) where immediate economic and social problems are regarded as under control, [...] it is inevitable that long term planning and concern for the long term scenario become the focus of attention" (p. 176). Needless to say, followed by an instrumental consideration, this paternalistic leader utilized the advantages enjoyed by a ruling party to control the rules and reform of electoral system in order to prolong the status of his ruling party. Thanks for Group Representation Constituencies to be effective from 1988, although the People's Action Party received less than 65 percent of votes from all qualified voters in that year, this ruling party could still be able to monopolize more than 90 percent of parliamentary seats (Chen, 1988b, p. 8). Particularly as for its nature of disproportional representation, all oppositions remained unchanged in an unfavorable condition under that kind of electoral reform not entirely working out with reference to Western-style democracy. In addition, for the design of all election groups under Group Representation Constituencies, the People's Action Party was meanwhile very successful in incorporating with ethnic minorities' representatives into the Parliament to further help enhance its legitimate ruling status.

For Deng Xiaoping, his continuous efforts paid for political modernization not with regard to an overall Westernized model which was initially with good intention, but finally, with limited success in practice while comparing with Lee Kuan Yew's one. On the one hand, for the effectiveness of the reform measures, Deng Xiaoping's Political System Reform could be better characterized as an administrative reform. As Zhao Ziyang pointed out, "the contents of Deng Xiaoping's speech could easily have caused people to believe that Deng Xiaoping was prepared to proceed with political modernization and democratization and to 
PAP

21,2

114

change the fundamentals of the political system. But it isn't like that" (Zhao, 2009, p. 248). As for the aforementioned scenario, Separation of Party and Government was prioritized to this paramount leader in post-Mao China, and it aimed to enhance the working efficiency, optimize Party leadership, as well as assist Economic Reform and Open-door Policy. In other words, Separation of Party and Government, dealing with how the Party coped with leadership, and how to lead well, was placed as the top. What came next was to decentralize authority to lower administrative levels, tackling the relationship between the central and the provincial governments, and the issue of provincial governments handing power down to various local levels. The last was to reduce the size of the administration. Another point was to improve efficiency (Zhao, 2009, p. 249). Yet, with regard to other democratic rights, as heavily emphasized by Western-style democracy, for example, organizing associations, assemblies and protests, they were taboos of Political System Reform, thus failing to entirely remedy the preexisting malpractices of the political institution. Just as rationales behind Four Cardinal Principles, this "big parent" would never allow China to adopt multi-party system as in the West; as a result, power was still highly centralized in a few political elites. In this, he clearly pointed out, "we shall develop Socialist Democracy, but it would be no good for us to act in haste. Also, it would be even worse for us to adopt Western-style democracy. If we conducted multi-party elections among one billion people, the country would be thrown into the chaos of an all-out civil war during the Cultural Revolution. A civil war does not necessarily require rifles and artillery; people can wage fierce battles only with fists and clubs. Democracy is our goal, but we must keep the country stable" (Deng, 1993, p. 285). Then, if we treat his reflection on misbehavior in politics as a benchmark to evaluate effectiveness of promoting such reform measures, most malpractices were still existent even after his several calling for Political System Reform from the early 1980s.

Although the problematic situation led by the life tenure in leadership posts was greatly improved through the newly-established tenure system in government organs, a series of negative influences brought by bureaucratism and paternalism remained serious as in Mao's China. On the other hand, as for the sustainability to keep promoting Political System Reform, its measures was just put into practice from 1987 to 1989 due to several instructions and speeches given by Deng Xiaoping. So his contribution to Political System Reform, such as enhancing the support from citizenry, was limited. Respecting Zhao Ziyang, who had been "elected" as the General Secretary in 1987, he decided to delegate power since the $13^{\text {th }}$ Party Congress, for example, restricting the Secretariat of the Central Committee's authority. In addition, the number of Secretary posts was reduced more than a half to further help improve administrative efficiency when being compared with that of the $12^{\text {th }}$ Party Congress (eds. Feng et al., 1991, p. 62). Needless to mention, reducing Secretary posts indicated the good intention and practice of this "big parent" on preventing overconcentration of power by practicing Political System Reform. Nonetheless, because of quite a great number of cadres' opposition, further removal of party organs advocated since the $13^{\text {th }}$ Party Congress could not be fully materialized, and the significance of party organs was again revitalized after 1989 (Chen, 1990, p. 114). That phenomenon clearly revealed the cumulated malpractices in political system, and worse still, along with the adverse effects to the sustainability of further deepening Political System Reform in a long run. In the $14^{\text {th }}$ Party Congress, Jiang Zemin being the new figurehead appointed by Deng Xiaoping announced a more cautious approach to promote Political System Reform, i.e., to rename Separation of Party and Government as Separation of Government and Enterprises (Wong, 2005, p. 99), with an ultimate aim of not overweakening the leading role of the Chinese Communist Party (Wong, 2005, p. 219), especially in the contexts of avoiding the threats brought by the dismemberment of the Soviet Union, i.e., Peaceful Evolution, and helping further deepen Deng Xiaoping's economically-oriented reform measures in the name of Socialist Market Economy. 
In the process of political modernization, a host of political issues would emerge, and unavoidably challenge the existing political system. History let us understand that there were different forms of political modernization: one of them was representative democracy originated from the West; and another was representational democracy (Wang, 2016, p. 234). King Yeo Chi put a further remark on the latter such as his coined term called "administrative absorption of politics" (King, 1981, pp. 127-146). To be deeply affected by Confucianism and newly-established states in a bi-polar world, Singapore, led by Lee Kuan Yew, and China, guided by Deng Xiaoping, demonstrated disparities and complexity in politics, in particular, the development of representative democracy throughout their tenures was full of uncertainties.

In an environment of having an authoritarian leadership, there had not been other effective political institutions as a kind of substitution in a polity. Thus, it is supposed representational democracy (e.g., "administrative absorption of politics" as coined by King Yeo Chi) might be noted as the only feasible political mechanism, especially for the better democratic transition. As Kishore Mahbubani (2014) justified, Asian nations "do not go straight from a soft authoritarian system ('hard government, soft economy') to a normal democracy (Western-style democracy). There is a transitional process. An interesting question that we should consider today is how this process began and why it began" (p. 18). In light of this, representational democracy in quite a number of situations can be regarded as a soft landing model's political modernization among certain Asian nations if their populations tend to smoothly transit to that under representative democracy as in the West. In the presence of such a feasible political mechanism, the recognition for political order is expected to be obtained by meeting the demand of elites. This kind of authoritarian governance is indeed a discreet way to attain Pareto improvement in political modernization not entirely following an overall Westernization. Considering the limited suitability of "administrative absorption of politics," it is just considered as a product used in the democratic transition. As King Yeo Chi asserted, "a low degree of politicization in society (in particular many Third World polities, for example, an independent Singapore and post-Mao China) is mostly essential to the legitimacy of such a government supported by the elite class. The extent of politicization will be further enlarged in the event of both the urbanization and the upward social mobility. Consequently, people in the very beginning excluded from the political arena can thus participate, enfeebling the elite class. In such a circumstance, the elite class should collaborate with the hoi polloi to sustain a more stable political system." (King, 2013, p. 252) With this holistic system to be implemented in full swing, "administrative absorption of politics" will therefore be effective as an expected political outcome.

To be clear, not only is that scenario a provisional means, but also a special political arrangement tailor-made for the establishment of a good government in the process of democratic transition. Prior to 1997, to be regarded as another evidence of "method of agreement" apart from the direct comparison of the duo within such temporal-spatial conditions, the historical case of colonial Hong Kong meanwhile showed a similar political system that was credited for its higher flexibility in governance. To satisfy the simultaneous needs of both the elites and the mass, such a system could continuously sustain itself. More significantly, that political pattern was able to attain more balance of interests among economic prosperity, social liberty as well as political authoritarianism (Kang, 2005, p. 84). Clearly, in the presence of "administrative absorption of politics," which is, in fact, an instance of representational democracy, an Asian polity without the full adoption of Western-style democracy can still safeguard benefits of distinctive stakeholders in its democratic transition.

In contrast to Deng Xiaoping, it is fair to comment that Lee Kuan Yew was more skillful to maintain order and stability for long in his homeland (Choi, 2017, p. 330). As a pragmatist, 
Deng Xiaoping appreciated and tended to project Singapore as his ideal governance model to China, which that kind of unique and yet successful Southeast Asian political modernization can effectively help sustain his East Asian homeland's economic growth while guaranteeing political stability by one-party rule. Borrowing the words from Stephan Ortmann and Mark Thompson, "China sees what it wants to see in Singapore, making the 'lessons' learned more caricature than reality. The key to Singapore's success as a society is that both modern and authoritarian are not simply its carefully calibrated repressiveness, but also its ability to promote meritocracy and allow a limited degree of political openness and organized political opposition in a multi-cultural society" (Ortmann and Thompson, 2016, p. 40). Thus, to Deng Xiaoping, the attractiveness of Singaporean model laid in the establishment of a good government under its authoritarian governance but as a sustainable economic powerhouse with reference to its "special national condition." These were without doubt compatible with each other. Yet, this view is sometimes with a characteristic of misunderstanding: many considered that the Singaporean political system to be static and mature, so they argued that it could be noted as the finalized model. The fact was, with regard to the parliamentary election held in 1968, initially based on universal suffrage. However, Lee Kuan Yew repeatedly introduced electoral reforms since the 1980s, such as how regular Members of Parliament could be as many as elected by Group Representation Constituencies from 1988 (Milne and Mauzy, 1990, pp. 95-96), in order to keep empowering the Cabinet's influence in post-Lee era. In the same year, just two years prior to his stepping down from Prime Minister, this political strongman meanwhile proposed the constitutional amendment, bringing about significant impacts to the President starting from the early 1990s. First, the President has been selected through direct election instead of appointment; and second, the President has been given the final decision-making power to veto Cabinet's personnel appointments and even its financial spending (Thio, 1997, pp. 113-114). A series of action indicated Lee Kuan Yew's political modernization that was incomplete and ongoing even during his last day in office. Thus to have the quality-assured political modernization, other Asian authoritarian leaders are expected to focus on "moderation principle," i.e., as much as to satisfy the simultaneous needs of both the elites and the mass of their polities, but not just repeating ideas of the Singaporean political system coordinated by Lee Kuan Yew that were not static and mature enough.

\section{Conclusion}

As most theories from the Western academic circle cannot wholly justify and/or explain distinctive modernization models initiated by leaders among Asian states after the Second World War, the author attempts to answer one question: Does the meaning of authoritarianism remain unchanged in the discourse of the East and the West? Concerning Lee Kuan Yew's Singapore and also Deng Xiaoping's China, their views on this political term were far different from those in the Western world. Apparently, authoritarianism includes multiple meanings: positive, neutral or negative meaning as shown in distinctive cases of our real world. Most critically, its semantic extension can be further likened to a panacea; such a word is inclusive of some other Eurocentric universal values, and it eventually helps legitimize a specific leader in governance. Especially for the positive meaning, as least likely recognized by Western scholars in the twentieth century and, meanwhile, being one of the significances of this study, the duo's authoritarian governance further compiling with their "special national conditions" as initiated by either the partial adoption of parliamentary democracy (the case of Lee Kuan Yew) or capitalism originated in the West (the case of Deng Xiaoping) seemed to be effective options. In terms of carrying on some but not all Eurocentric universal values in their authoritarian governance, the two political strongmen, on the one hand, could avoid chaos and instability without shaking crucial conventions; on the other hand, largely got rid of the potential ideological 
conflicts with the West, enabling an independent Singapore and post-Mao China to earn more time and opportunities to establish their good governments despite adverse conditions (e.g., geopolitical constraints; Cold War's influences). Borrowing the very similar view from Huang Biao, to establish "a good government outweighs any other values" (Huang, 2014, p. 156). In other words, a good government is better to come prior to Western-style democracy, and the practice of Western-style democracy sometimes should not be noted as the best solution to nations outside the US and Europe. As seen from the duo's tenures, it is fair to sum up their good but authoritarian governments that could effectively help boost economy, which, as a result fostered social stability for decades. Differing from Asian polities fully practicing Western-style democracy, this is undeniable that the duo as highlighted in this paper always regarded establishing a good government as their same and yet ultimate modernization goal. Not surprisingly, the good progress to gradually achieve such an elegant goal did enhance legitimacy of their authoritarian leadership.

Socialism pursues equality in theory, but leads to poverty and red tape in practice; capitalism embraces work efficiency in theory, but results in wasting of resources, and social inequality in practice. Of all three merits to establish a good government under authoritarian leadership in the East not wholly following the underlying principles of Western-style democracy: policy-outcome benefits; administrative efficiency; and socioeconomic advancement, Lee Kuan Yew and also Deng Xiaoping to be seen as "positive" cases of such an Asian authoritarian governance under "method of agreement" did not struggle with a series of former dogmatic ideologies; instead, their pragmatic beliefs to lower governance costs mostly resulted in the implementation of "moderation principle" throughout their policy-making (Choi, 2017, pp. 332-333). Take Political Modernization as a particular example to be discussed and analyzed in this paper, their art of authoritarian governance would be more or less able to help speed up the Pareto improvement among Party, state and society, by having most, if not all, stakeholders as winners in such way of modernization not fully based on Eurocentric universal values. In an Asian society with a lower degree of politicization, so that once being required to choose from either Westernstyle democracy or authoritarianism, the model of having such way of modernization in the lead of a "clever" authoritarian leader seems to be advantageous because of its lower cost in governance. Apparently, history already showed there were always spaces for political exploration, and hardly did unfounded forecasts or predictions have any pragmatic values.

\section{References}

Chan, H.C. (1971), Singapore: The Politics of Survival, 1965-1967, Oxford University Press, Singapore.

Chan, H.C. (1986), "The PAP in the nineties: the politics of anticipation”, in Jackson, K.D., Baribatra, S. and Djiwandono, J.S. (Eds), ASEAN in Regional and Global Context, Institute of East Asian Studies, University of California, Berkeley, pp. 163-182.

Chen, E.I.H. (1988a), "Changes in the theory of class struggle in Post-Mao Mainland China", in Chang, K.Y. (Ed.), Ideology and Politics in Twentieth Century China, Institute of International Relations, National Chengchi University, Taipei, pp. 82-115.

Chen, H.Y. (陳鴻瑜) (1988b), “1988 Nian Xinjiapo Guohui Xuanju (1988年新加坡國會選舉)”, Wenti yu Yanjiu (《問題與研究》), Vol. 28 No. 1, pp. 1-11.

Chen, L.F. (陳烈甫) (1982), Li Guangyao Zhixia de Xinjiapo (《李光耀治下的新加坡》), Taiwan Shangwu Yinshuguan, Taibei.

Chen, Y.Z. (陳一諮) (1990), Zhongguo: Shinian Gaige yu Bajiu Minyun (《中國：十年改革與八九民運》), Lianjing Chuban, Taibei. 
PAP

21,2

118

Choi, K.H. (2017), "The art of governance of authoritarian leaders in Asia: a comparative study of Lee Kuan Yew and Deng Xiaoping”, unpublished doctoral thesis, Department of History, The Chinese University of Hong Kong, Hong Kong.

Chua, B.H. (1995), Communitarian Ideology and Democracy in Singapore, Routledge, New York, NY.

Deng, X.P. (鄧小平) (1993), Deng Xiaoping Wenxuan (《鄧小平文選》), Vol. 3, Renmin Chubanshe, Beijing.

Deng, X.P. (鄧小平) (1994), Deng Xiaoping Wenxuan (《鄧小平文選》), Vol. 2, Renmin Chubanshe, Beijing.

Feng, W.B. (馮文彬), Gao, D. (高狄), Wang, M.L. (王茂林) and Wang, R.P. (王瑞璞) (Eds) (1991), 1921-1991: Zhongguo Gongchandang Jianshe Quanshu (《1921-1991: 中國共產黨建設全書》), Shanxi Renmin Chubanshe, Taiyuan.

Fukuyama, F. (1989), "The end of history?”, The National Interest, Vol. 16, pp. 1-18.

Fukuyama, F. (2013), "What is governance?”, Governance: An International Journal of Policy, Administration, and Institutions, Vol. 26 No. 3, pp. 347-368.

Goodman, D.S.G. (1994), Deng Xiaoping and the Chinese Revolution: A Political Biography, Routledge, London.

Guo, B.G. (2010), Chinese Quest for Political Legitimacy: The New Equity-enhancing Politics, Rowman and Littlefield, Lanham.

Huang, B. (黃彪) (2014), Zhongguoshi Minzhu “Lunshu”zhi Chutan (《中國式民主「論述」之初探》), Zhizhi Xueshu Chubanshe, Taibei.

Kang, X.G. (康曉光) (2005), Renzheng: Zhongguo Zhengzhi Fazhan de Disantiao Daolu (《仁政 : 中國 政治發展的第三條道路》), Bafang Wenhua, Xinjiapo.

King, A.Y.C. (1981), "Administrative absorption of politics in Hong Kong: emphasis on the grass roots level", in King, A.Y.C. and Lee, R.P.L. (Eds), Social Life and Development in Hong Kong, The Chinese University Press, Hong Kong, pp. 127-146.

King, A.Y.C. (金耀基) (2013), Zhongguo Zhengzhi yu Wenhua (《中國政治與文化》), Niujin Daxue Chubanshe, Xianggang.

Kwang, H.F., Warren, F. and Sumiko, T. (1998), Lee Kuan Yew: The Man and His Ideas, Singapore Press, Singapore.

Kwang, H.F., Ibrahim, Z., Hoong, C.M., Lim, L., Low, I., Lin, R. and Chan, R. (2011), Lee Kuan Yew: Hard Truths to Keep Singapore Going, Straits Times Press, Singapore.

Leifer, M. (2000), Singapore's Foreign Policy: Coping with Vulnerability, Routledge, New York, NY.

Mahbubani, K. (2010), "New Asian perspectives on governance”, Governance, Vol. 23 No. 2, pp. 205-208.

Mahbubani, K. (2014), "Three scenarios for Singapore's political future”, in Koh, G. (Ed.), Singapore Perspectives 2013: Governance, World Scientific, Singapore, pp. 17-20.

Milne, R.S. and Mauzy, D.K. (1990), Singapore: The Legacy of Lee Kuan Yew, Westview Press, Oxford.

Mullins, W.A. (1972), "On the concept of ideology in political science", American Political Science Review, Vol. 66 No. 2, pp. 498-510.

Nathan, A.J. (1990), China's Crisis: Dilemmas of Reform and Prospects for Democracy, Columbia University Press, New York, NY.

Naughton, B. (1993), "Deng Xiaoping: the economist", The China Quarterly, Vol. 135, pp. 491-514.

Ortmann, S. and Thompson, M.R. (2016), "China and the 'Singapore' model”, Journal of Democracy, Vol. 27 No. 1, pp. 39-48.

Pearson, M. (1999), "China's integration into the international trade and the world: investment regime”, in Economy, E. and Oksenberg, M. (Eds), China Joins the World: Progress and Prospects, Council on Foreign Relations Press, New York, NY, pp. 161-205.

Pitkin, H.F. (1967), The Concept of Representation, University of California Press, Berkeley.

Quah, J.S.T. (1988), "Controlled democracy, political stability and PAP predominance: government in Singapore", in Langford, J.W. and Brownsey, K.L. (Eds), The Changing Shape of Government in the Asia-Pacific Region, Institute for Research on Public Policy, Halifax, NS, pp. 125-169. 
Quah, J.S.T. (2015), “Lee Kuan Yew's enduring legacy of good governance in Singapore, 1959-2015”, Asian Education and Development Studies, Vol. 4 No. 4, pp. 374-393.

Skocpol, T. (1979), States and Social Revolutions: A Comparative Analysis of France, Russia, and China, Cambridge University Press, Cambridge.

Thio, L.A. (1997), "The elected president and the legal control of government: quis custodiet ipsos custodes?", in Tan, K. and Lam, P.E. (Eds), Managing Political Change in Singapore: The Elected Presidency, Routledge, London, pp. 100-143.

Vogel, E.F. (2011), Deng Xiaoping and the Transformation of China, Belknap Press of Harvard University Press, Cambridge, MA.

Wang, S.G. (王紹光) (2016), Zhongguo Zhengdao (《中國政道》), Zhonghua Shuju, Xianggang.

Wong, Y.C. (2005), From Deng Xiaoping to Jiang Zemin: Two Decades of Political Reform in the People's Republic of China, University Press of America, Lanham, MD.

Xinjiapo Lianhe Zaobao (新加坡聯合早報) (Ed.) (1994), Li Guangyao: 40 Nian Zhenglun Xuan 《李光耀:40年政論選》), Xinjiapo Baoye Konggu, Xinjiapo.

Zhao, Z.Y. (2009), Prisoner of the State: The Secret Journal of Chinese Premier, Simon and Schuster, London.

\begin{abstract}
About the author
Franky K.H. Choi, PhD in History, received MSocSc in General Education (Academic Distinction; and Dean's List) from The Chinese University of Hong Kong. His recent research focuses on domestic politics and political histories of Asian polities. From 2008 to 2016, he served as College Lecturer at HKU SPACE Community College (Arts and Humanities; and Division of Social Sciences). Meanwhile, he was appointed as Course Coordinator of Hong Kong and Chinese Societies in Transition. In 2018, Hong Kong Chinese Culture Development Association invites him as a guest on Metro Radio FM 99.7, to provide an opportunity for audiences understanding the history of Hong Kong and Singapore, particularly in a comparative approach. He is currently writing a book entitled Authoritarian Leadership and Good Governance in the Twentieth Century's China and Singapore: A Comparative Study of Deng Xiaoping and Lee Kuan Yew. Franky K.H. Choi can be contacted at: franky.choi@link.cuhk.edu.hk
\end{abstract}

For instructions on how to order reprints of this article, please visit our website:

www.emeraldgrouppublishing.com/licensing/reprints.htm

Or contact us for further details: permissions@emeraldinsight.com 